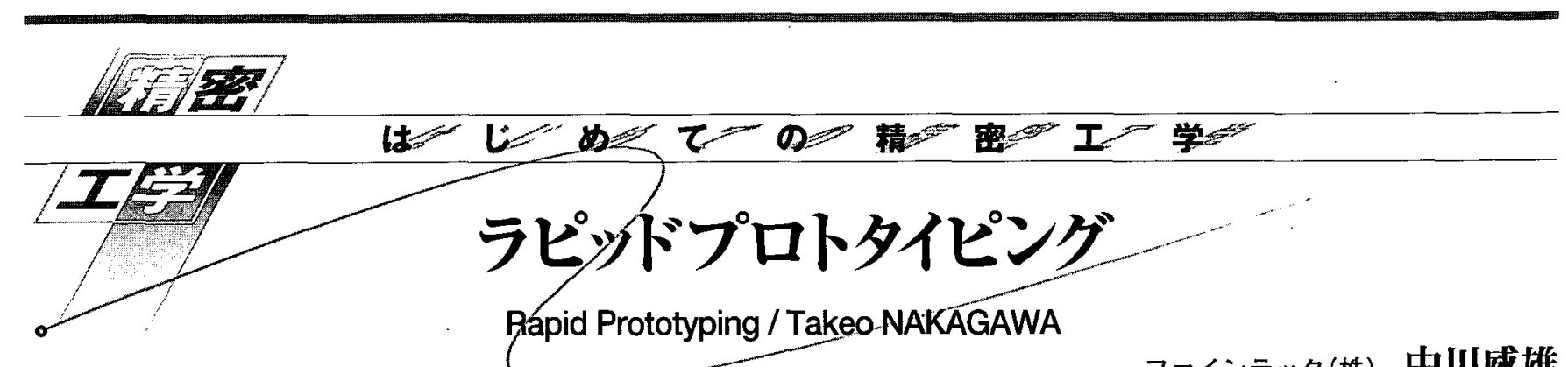

ファインテック(株) 中川威雄

\section{1. 試作品づくり迅速化の背景}

"Rapid Prototyping"とは，試作づくり（Prototyping）を迅 速（Rapid）に行なうことをいいます。最近の製造業は生産 のグローバル化が進むと共に, 企業間の競争は一層厳しくな り，それに応じて新製品開発競争も激化してきました。この 新製品競争では，開発期間の短縮が至上命令となっています。 㢼品企画から発売までの期間が長いと，賞味期限が切れた新 製品となる危険があるのです。迅速に開発された新製品も， ライバル会社の製品に見劣りすれば売行きに影響を与えます し，発売後に欠陥が見つかったのでは，リコールなど大変な ことになります。そのため，開発の短期化にもかかわらず， 試作品をつくって十分なチェックをして，製品を熟成するこ とが必要なのです.

大量生産に使われる多くの機械部品は，金属材料は鋳造や プレス加工，樹脂材料では射出成形といった方法で製造され ますが，これらの方法ではいずれも型を使っています．製品 の設計が終わって製造を始める時，いちばん時間と費用がか かるのがこの型づくりなのです．試作品づくりにまでわざわ ざ型をつくっていたのでは，時間も金もかかり迅速な新製品 開発というわけにはいきません，その間に設計変更されるこ とも多いので，量産にはまた新たな型を準備しなければなり ません，そのため試作品づくりには簡易な型を使った成形や， 切削加工や接着・溶接を組合わせて手づくりで行なうなど， 時間と費用を節約する色々な工夫がなされています。そうし た中で今から 20 年程前に Rapid Prototyping という新しい試 作品づくりの手法が出現しました。

\section{2. 型を使わない新しい生産手法}

機械部品を製造するには，材料の塊りを切削加工のように 切取って除去するか，材料を型に沿わせて変形させ造形する のがこれまでの主な手段でした．新しく登場した手法は，材 料を付着させて造形する付加加工と呼ばれる方法です，基本 的な原理は，立体形状の機械部品を薄い層状物を積み重视た ものとみなし，何らかの手法で異なる形状の薄層をつくり， 一層ずつ重ねて積み上げていく“積層造形”とよばれる手法 です，立体地図をつくるのに，等高線に沿って切取った厚紙 を重ねていく方法がありますが，そ机と同じ方法と見なすこ とができます。

このような立体造形法はこれまで手作業でした。しかしこ れが完全に自動的に行われ，機械部品の生産技術として確立 された点が新しいのです，それには機械部品の設計が $\mathrm{CAD}$ 化されたことが大きな影響を与えました。つまりこの造形法 では立体形状が 3 次元 $\mathrm{CAD}$ を使って表現され，そこから薄 くスライスしたデータがつくられることを前提としていま す。造形装置はそのデータを使用して自動的に薄層を作り， さらに積檿していく機能を備えています。

このスライスデータから薄層を作る工程は，プリンタ技術 の応用に近いものです，そのためこの造形装置には近年大い に発展したコピー機や FAX の印刷用のプリンタ技術が随所 に活用されています。これらのことから積層造形は，3次元 $\mathrm{CAD}$ の普及とともに発展した IT 化時代の新しい機械部品の 製造法といえるのです。

\title{
3. 各種の積層造形法
}

積層造形法には図1のように数多くの手法が開発されてい ます．その手法の差はどのような材料の薄層をどのように製

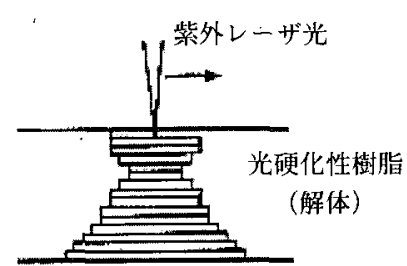

(1)光造形法

インクジェット

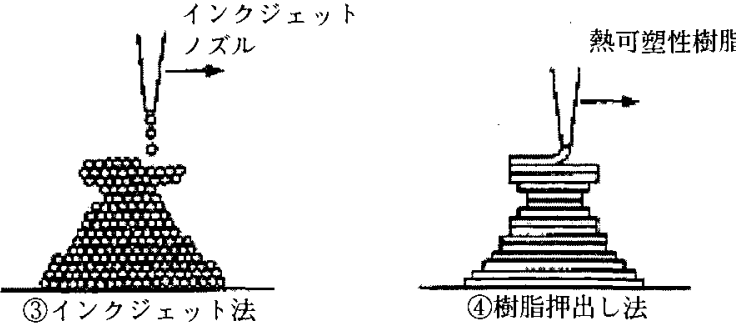

$\mathrm{CO}_{2}$ レーザ光または

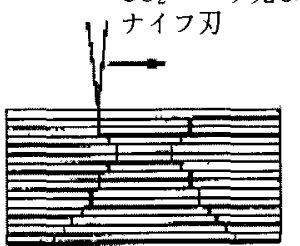

(5) シート切断法

图 1 各種積層造形法

*レーザ光加熱の代わりにインクジエットノズルり接着剂在滴下して粉末を固める方法もある
(2)粉末焼結法"

(4)樹脂押出し法

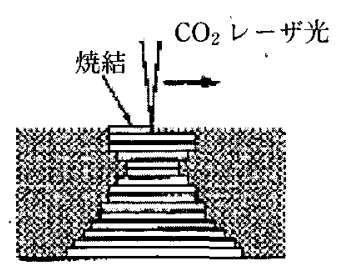




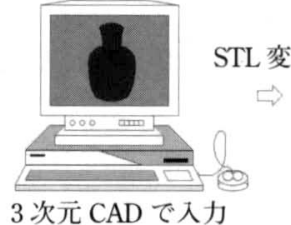

された形状デーダー

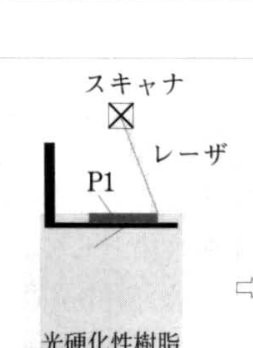

第 1 層 P1 層の硬化

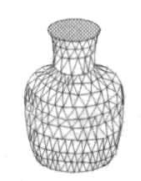

STL データ表現

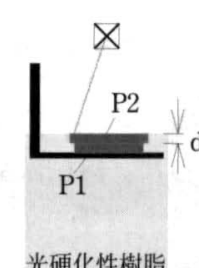

第 2 層 P2 層の硬化

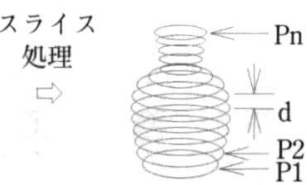

$\mathrm{N}$ 層にスライスさ

れた数值データ

\section{】成形加工}

図 2 光硬化性樹脂を用いた積層造形 (光造形)

作し，どのように付着させ積層させていくかです，以下にそ の主なものを紹介しましょう。

\section{1 光硬化樹脂法}

高分子材料の中には, 通常は液体ですが紫外光を照射する と硬化し固体となる光硬化性樹脂があります．図 2 に示すよ うにこの液体の薄い層をつくり，その液面に紫外光のビーム を照射し，このビームをスライスデータに沿って走査するこ とにより，所要形状の薄層を固化させることができます。そ の後固体化した薄層部分を液中に沈めて固化部分の上に前回 と同様な液層を構成し，再度ビームを照射して次の層形状を 固めます。これを繰返すことにより，スライスデータを積重 ねた階段状の立体形状を造形することができます．オーバハ ング部をそのままでは造形できませんので，下からの支え部 分をあらかじめ設計し同時に造形しておくことが必要です.

この方法は積層造形法の中で, 最初に開発された方法で微 細な形状から大物部品まで比較的精度の高い造形ができるこ ともあり広く活用されています．光ビームの照射によっての モノゔくりということで特に光造形法とも呼ばれます.

\section{2 粉末焼結法}

液状樹脂の代わりに微細な粉末材料を使う方法もありま す，粉末は液体と同じように流動するので，まず薄い圧粉層を ロールを押し付けてつくるのですが，その後の粉末を互いに 接着する方法がこの造形法の鍵となります．接着するにはレー ザ光を加熱ビームとして照射し，粉末の粒を溶融させるか粒 子間を接着または焼結して固体層とする方法が取られます. このとき加熱時には下の層との接合も同時に行います。最後 は圧粉体の中から造形品を取出すのですが，オーバハング部 があっても特別なサポートを造形する必要がないことも利点 の 1 つです.

また，この粉末接合方法では色々な粉末材料が使用できる のも利点とされ，量産時と同質の樹脂粉末を使えば，高強度 な試作品も造形できます。また耐熱性のある鋳物砂を樹脂コー ティングしておき，コーティング剤を介して砂粒を焼き固め

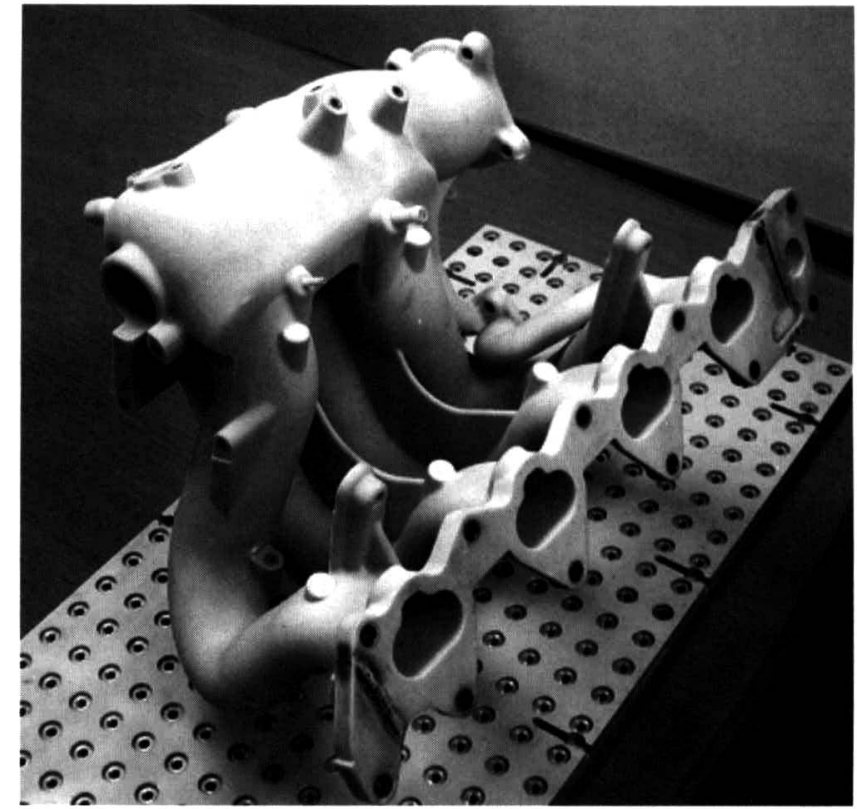

図 3 積層造形サンプル (自動車エンジン用インテークマニホールド) 提供：アスペクト

れば，金属鋳造用の鋳型としても利用できます。さらに原料 に金属粉末を使うこともできますが，今のところ多孔質の金 属造形品となり，強度を増すため空孔を穴埋めする必要があ ります。

\section{3 インクジェット滴下法}

粉末を固める手法として，インクジェットノズルより印刷 インクの代わりに接着剤の粒を滴下させても粉末同士を接合 できます，通常印刷用プリンタで使われる多数並べたノズル を流用すると, 比較的安価な装置で高速度に造形できる利点 があります。

インクジェットノズルから接着剤ではなく，後で固まる液 状の樹脂を滴下しても造形できます。例えば光硬化性樹脂を 落とし，紫外光を照射して固めることはできます．また加熱 溶融した低融点のワックスや樹脂を滴下して造形品を得るこ とができます。このうちワックス造形品はロストワックス鋳 造品のモデルとして使い，金属部品に転換できます。

\section{4 樹脂押出し法}

細いノズル穴から溶融樹脂を押出し，この押出し線材を走 査して平らな薄層を創生し，それを積層し造形することも可 能です．この場合もオーバハング部にはサポートの造形を必 要とします。この方法の利点は，最も多い造形対象部品があ る熱可塑性樹脂と全く同じ材質の樹脂が使用できる点にあり ます，試作となると強度や手触りの感触といったものを評価 するので，同一材質の利点は大きいのです，そのためもあつ て各種積層造形法の中では, 販売台数からみると最も普及し ている方式とみられています。

\section{5 切断シート積層法}

薄いシート材料をレーザや刃物で切断し，それを自動積層 接着すれば同じように立体造形が可能です。実際には積層し た後で切断する方式がとられます。この場合シート材として 


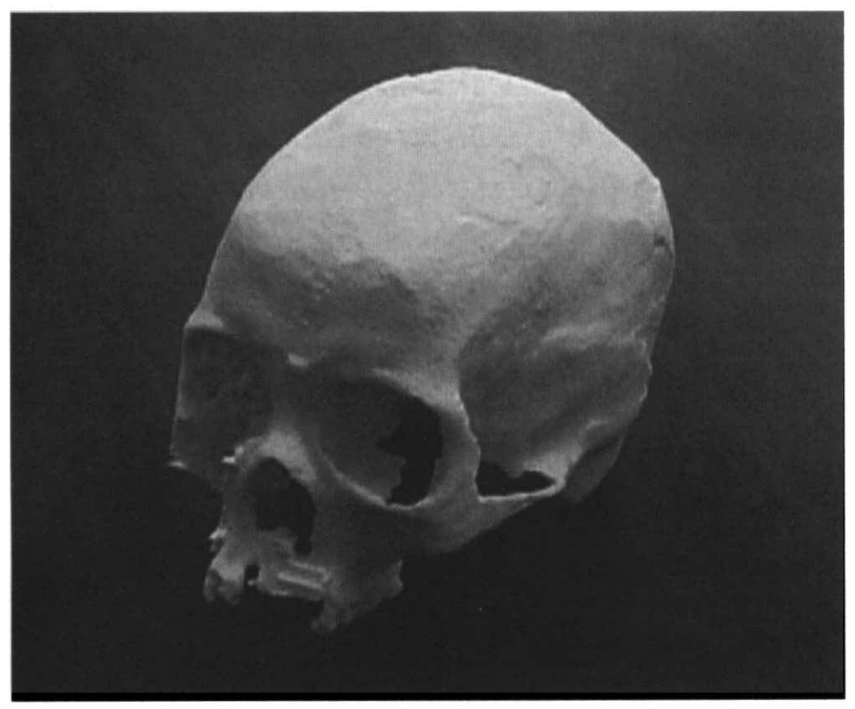

図4 CT データからの積層造形 提供：アスペクト

は紙や樹脂シートが使用されます。この方法で中空の形状の 造形をする場合には, 分割した状態で造形し中味を取出す必 要があります。

\section{4. 積層造形品の用途}

冒頭にも述べましたが, 積層造形法は図 3 のような試作品 づくりの方法として生れた新しい加工法です。さらに3D $\mathrm{CAD}$ データの形状確認用の実体モデルブくりにも普通に用 いられるようになりました。そのため積層造形は 3 次元プリ ンタとも呼ばれています.これらの 3 次元プリンタとしての 用途には比較的安価な造形装置が用いられています。

2 次元画面の中でいくら CAD データに影をつけたり回転 させて見ることができても，実体化されたモデルを眺めたり， 手で触れることには及ばないところがあります。このモデル を活用することによって，機械部品の設計や，金型設計， CAM データづくりといった作業が, より容易にかつ確実に できることも多いのです。このように積層造形は単に試作品 を迅速に製作するだけでなく, 生産システムが $\mathrm{CAD}$ を心 とする IT 化が進む中で, リバースエンジニアリングやコン カレントエンジニアリングには欠かせないものとなってお

り, Rapid Manufacturing の重要な役割を占めています.

さらに，積層造形モデルは営業用などのプレゼンテーショ ン資料や教育用資料作成にも力を発揮することがわかってい ます。また，医療用に患部などの CT や MRI の立体スライ スデータより, 図4のような人体の複雑な立体形状情報を得 て, 必要部分を造形することも行われています。この造形品 は外科手術のシミュレーションやインプラント製作に活用さ れています。

\section{5. 積層造形の技術的課題}

積層造形法も良いことばかりではありません，積層造形で は薄層を積重ねるため表面に段差残るので, 高い形状精度を 得るためにできるだけ薄い層を使う努力がなされています.
しかしどんなに薄くしてもこの段差は生ずるので, 後の仕上 げ工程において手みがきで平滑化しなければならず，またサ ポートの除去などある程度の手作業は残り，完全に自動化と はいきません，それでも従来の切削法による試作品づくりに 比べれば, 大幅な簡略化が可能となりました。

この方法は CAD で設計できるものはどんな形状でも，時 には実際に加工不可能な形状まで造形できる利点がありま す。一番の問題はそれぞれの手法ごとに使用可能材料に制約 があることで, 形状確認用には問題はなくても, 試作品とし て強度試験に使用できないことも多いのです。

\section{6. 金属直接造形と型への応用が今後の課題}

機械部品には鋳造，鍛造，プレス品など金属製部品が非常 に多く使われています。しかし既存の積層造形法では，まだ 完全にち密な金属造形品を直接製造することができないこと が課題となっています．金属造形は金属粉末から造形する方 法が採られます。一番の技術的な困難さは，金属粉末をレー ザ光などで高温溶融するのですが, 表層の溶融層が冷却する とき大きな内部応力を発生させ, 造形品を変形させてしまう のです。この解決策として高温槽内で造形したり, 切削で歪 分を削取りながら造形する方法などが考案されていますが， まだ広く使われる技術までには育っていません。

金属積層造形の用途で, 今後最も大きく期待されている用 途は，Rapid Tooling といわれる金型製作への応用です。そ のために金属材料の積層造形技術に大きな期待がかかってお り，世界中で多くの研究者がその開発に取組んでいます．金 属積層造形が完成すれば，世の中の製造技術に大きく貢献す ると思われます。

\section{7. 特許騒動とベンチャー起業}

積層造形法は最近登場した新しい技術ですので, ベンチャー の起業も相次ぎ，また多くの特許係争も生じました。今後の 参考のためここで起こったことを振り返ってみたいと思いま す.

1. 最初に誕生した光造形法は名古屋市工業研究所の小玉秀 男氏の個人発明なのですが，本人は不幸にも実用開発が 進んでいることに気づかず，申請特許の審査請求を意り 無効となりました。 また少し遅れて日米の研究者 2 人の 特許も出されていました。

2. 光造形法はその後, 別の米国人の C.W.Hull 氏からも世 界中に特許申請され，実際に装置メ一カとして実用化を やり遂げたのですが，特許申請内容は広範囲にわたり， ライバルメーカは特許料の支払いや業務の停止に追い込 まれることとなりました。

3. その他の各種の積層造形法の発明は，主に米国で短期間 の内に競うようになされ, 総じてわが国は基本特許の取 得で敗退しました。そのためもあって装置メーカとして 米国企業の活躍が目立っています. 
4. 粉末焼結法も米国でいち早く特許申請が出されたのです が，外国出願をしなかったため米国以外泣自由に使用で きる状態となりました. 類似のことは最初の特許を含め， 日本の研究者の発明にも多く見られます。

5. 大学や研究機関から幾つかの新造形法や実用技術が生れ， それを基に主に米国で大学発べンチャーが誕生しまし た.

6. 日本での公的研究機関での職務発明や特許申請の制度が 整備されていない時期であったため，実際の実用化とな ると所有権の帰属など微妙な問題も含んでいました。

7. そろそろ 20 年が経過し最初の頃の基本特許は切れつつ あります。しかし周辺特許などで固められており，当分 は新たな参入はできない状況が続いています。

8. 各種の造形法はその特徵を生かした形で活用されていま すが，相互の競争の中で栄枯盛衰が見られ，衰退し消え つつあるものもでています。

9. 造形装置メーカや造形事業にはべンチャ一企業が多く, 故しい競争の中で合併や M\&Aが繰返され，今も大変な グローバルな開発競争の中にあります。

10. 日本では主に光造形法に多数メーカの参入が見られ，小 さなパイを分け合って競争が厳しく，その分装置の質は 向上しているものの経営的には苦しい状況が続いていま
す.

これらを通じて米国の特許戦略の強さと巧妙さ，ベンチャー 企業の波乱に富んだ発展と，係わり合った人材の流動が見ら 机ました．その中に明らかな日米の企業経営のやり方と技術 熟成の差が見えてくるのは興味深いものでした。

\section{8. おわりに}

長い歴史を持つモつつくり技術には，積層造形のようなま さに画期的ともいえる技術は減多に生れてはこないもので す。この技術が初めて登場して 20 年，装置はすでに世界中 で約 2 万台が使われています。新製品開発が重要な先進工業 国では不可欠なモノづくり手段としての確たる地位を占める に至っています，同時に日本の得意とする熟練技能者の匠の 技の価値も一部減ずることになっています．モノづくり技術 は横着な顧客に都合の良いように発展するのですが，同時に その技術を開発するものにとっては決して楽を与えてはくれ ない宿命を持っていることを痛感します。

\section{参 考 文 献}

1）中川威雄・丸谷洋二編：積層造形システム, 工業調查会（1996）

2）中川威雄：金型がわかる本，日本実業出版，(2006）

3) Terry Wohler: Wohler's Report 2006 